\title{
PEMBERDAYAAN FASILITATOR BELAJAR SISWA SMA PADA LEVEL MENENGAH
}

\author{
Yubali Ani ${ }^{1}$, Ashiong Munthe ${ }^{2}$, Widiastuti ${ }^{3}$ \\ ${ }^{123}$ PGSD, Universitas Pelita Harapan \\ yubali.ani@uph.edu ${ }^{1}$, ashiong.munthe@uph.edu ${ }^{2}$, widiastuti.tc@uph.edu ${ }^{3}$
}

\begin{abstract}
Abstrak
Kegiatan pemberdayaan fasilitator belajar yang dilakukan kepada siswa SMA level menengah (dua) adalah untuk memperlengkapi para peserta di dalam menjawab kebutuhan yang ada di lapangan. Kegiatan pemberdayaan ini diperuntukkan kepada siswa/i SMA yang sudah lulus mengikuti pemberdayaan level dasar (satu). Tujuannya adalah agar para fasilitator belajar mampu merencanakan, melaksanakan, dan melakukan penilaian dengan baik terhadap kegiatan belajar dan mengajar yang mereka lakukan di lingkungan masing-masing. Metode yang digunakan pada kegiatan ini adalah pemberian materi, latihan mandiri dan kelompok, diskusi, tanya jawab, mentoring, dan presentasi. Kegiatan dilakukan setiap hari Sabtu 2x dalam sebulan, bertempat di daerah Sentul. Hasil yang diperoleh dari kegiatan ini, tidak berjalan sesuai dengan rencana dengan maksimal dikarenakan Pandemi Covid-19. Para peserta lebih dilatih untuk terbiasa menggunakan perangkat HP dan aplikasi yang ada didalamnya, hal ini dikarenakan keterbatasan perangkat yang dimiliki oleh para peserta. Oleh karena itu, kegiatan ini kami beri nama "Pra-kegiatan" di mana para peserta dipersiapkan untuk dapat mengikuti kegiatan selanjutnya di semester depan dengan terbiasa menggunakan perangkat baik Hp maupun Laptop.
\end{abstract}

Kata Kunci: pemberdayaan, fasilitator belajar, level menengah

\section{PENDAHULUAN}

Dalam melaksanakan program pembelajaran masyarakat, terdapat dua komponen utama yang saling berkaitan satu sama lain, yaitu komponen peserta didik dan komponen pendidik atau fasilitator yang memfasilitasi pembelajaran (Yatimah, 2015). Pendidik atau fasilitator pada program pembelajaran masyarakat memiliki peran untuk membantu warga usia belajar khususnya dalam proses pembelajaran yang sedang berlangsung. Pembelajaran merupakan suatu proses yang berfungsi membimbing warga usia belajar di dalam kehidupannya, yakni membimbing dan mengembangkan diri sesuai dengan tugas perkembangan yang harus dijalani oleh anak PP (Majid, 2013).

Menurut Sardiman (2012), peran pendidik, antara lain: 1) Organisator. Fasilitator belajar merancang tempat belajar dengan baik sehingga anak PP menjadi nyaman saat belajar.; 2) Motivator. Langkah yang dilakukan oleh fasilitator belajar dalam memotivasi anak PP adalah dengan menggunakan ice breaker dan pemberian reward kepada peserta didik.; 3) Director/Pengarah. Para fasilitator belajar memfasilitasi kegiatan belajar anak PP melalui pemanfaatan media (bahan dan alat) yang ada di lingkungan mereka dan mengoptimalkannya.; 4) Inisiator. Para fasilitator belajar menggunakan strategi pembelajaran dalam 
peningkatan pengetahuan, pengembangan sikap, dan pengembangan keterampilan anak PP.; 5) Transmiter. Para fasilitator belajar membuat peraturan dan prosedur di dalam kegiatan belajar yang disesuaikan dengan tingkat perkembangan anak PP.; 6) Fasilitator. Para fasilitator belajar membuat proses belajar mengajar yang disesuaikan dengan kondisi anak PP di lingkungan mereka baik dalam perencanaan, pelaksanaan hingga evaluasi pembelajaran.; 7) Mediator. Para fasilitator belajar memiliki pengetahuan dan pemahaman tentang aneka ragam media pembelajaran yang menjadi alat komunikasi dalam kegiatan belajar mengajar yang lebih efektif.; 8) Evaluator. Para fasilitator belajar membuat penilaian untuk mengetahui keberhasilan pencapaian tujuan pembelajaran.

Kehadiran fasilitator belajar yang digagas oleh Yayasan Emmanuel melalui outreach program (OP) memberikan dampak bagi lingkungan di tempat tinggal para fasilitator belajar. Para fasilitator belajar merupakan siswa SMA (kelas 2-3) yang mendapatkan pelatihan untuk dapat mengajar warga usia belajar yang ada di lingkungan tempat mereka tinggal. Para fasilitator belajar ini sudah mendapatkan pelatihan level dasar selama satu tahun mengenai pengelolaan kegiatan belajar mengajar secara sederhana. Pelatihan pemberdayaan fasilitator belajar merupakan salah satu bagian dari Pendidikan non formal dimana berfungsi sebagai sarana pembinaan dan pengembangan kemampuan untuk meningkatkan kualitas para fasilitator belajar dalam mengajar anak PP di lingkungan mereka tinggal sesuai dengan kebutuhan di lapangan (Dytta, 2016).

Adapun pelatihan yang sudah mereka peroleh pada level dasar, antara lain: 1) mengajarkan Bahasa Indonesia dalam mengeja dan membaca; 2) mengajarkan Matematika dasar dalam konsep operasi hitung sederhana; 3) menjelaskan konsep sebuah materi melalui mind mapping; 4) bercerita melalui buku cerita yang dibuat mengenai diri sendiri; 5) menjelaskan sebuah permainan sederhana yang dirancang bersama; 6) menjelaskan prosedur kelas; 7) merancang sebuah pembelajaran; 8) melaksanakan pembelajaran sesuai dengan kondisi di lapangan; dan 9) membuat penilaian terhadap pembelajaran yang dilakukan. Para fasilitator belajar ini pun sudah diperlengkapi dengan kemampuan merencanakan, melaksanakan, dan mengevaluasi sebuah pembelajaran sesuai dengan konteks di lapangan.

Para fasilitator belajar juga mendapatkan materi mengenai komunikasi yang efektif di dalam pembelajaran, karena fasilitator belajar juga adalah seorang komunikator. Menurut Majid (2013), Komunikasi dalam sebuah pembelajaran dapat dikatakan efektif, jika didalamnya terdapat aliran informasi dua arah antara komunikator (fasilitator belajar) dengan komunikan (anak PP), dan informasi tersebut mendapatkan respons sesuai dengan harapan dari kedua pelaku komunikasi. Adapun aspek yang perlu dicermati dalam membangun sebuah komunikasi yang efektif, antara lain: 1) Kejelasan. Penggunaan Bahasa dalam informasi dibuat secara jelas dan mudah diterima.; 2) Ketepatan. Pengunaan Bahasa yang tepat dan informasi yang disampaikan harus benar.; 3) Konteks. Informasi yang disampaikan kepada anak PP harus sesuai dengan kondisi lingkungan.; 4) Alur. Informasi yang disajikan tersusun dengan sistematis.; 5) Budaya. Dapat berkomunikasi dengan menyesuaikan budaya dari orang yang diajak bicara.

Keberhasilan mereka dalam mengajar terlihat dari jumlah PP (partisipan) belajar yang bertambah Hal ini dikarenakan saat mengajar di lingkungan tempat mereka tinggal, para fasilitator mempersiapkan pembelajaran dengan baik. Mereka melakukan tahapan-tahapan berikut saat mengajar, antara lain: 1) merancang pembelajaran sederhana; 2) membuat alat peraga sesuai materi ajar dan sesuai konteks lingkungan yang ada; 3) membuat prosedur belajar; 4) membuat penilaian berdasarkan tujuan yang hendak dicapai. Ketika tahapan-tahapan ini dilakukan, maka proses pembelajaran berjalan dengan baik dan menarik minat anak PP untuk belajar.

Kegiatan yang dilakukan oleh para fasilitator belajar merupakan kegiatan pendidikan nonformal. Menurut Syamsi (2010), Pendidikan nonformal merupakan kegiatan pelayanan pendidikan di luar sistem sekolah. Kegiatan ini berlangsung selama hidup, disesuaikan kondisi di lapangan, terencana dan teratur, serta memiliki tujuan dalam mengaktualisasikan kemampuan manusia seutuhnya dalam hal belajar-mengajar agar mampu meningkatkan taraf hidupnya. Pada kegiatan pendidikan nonformal ini, anak PP (partisipan) adalah warga belajar dari tingkat anak

$$
\text { Pendidikan }
$$


usia dini sampai sekolah dasar. Seperti yang kita ketahui bahwa tujuan dari pendidikan nonformal adalah untuk memenuhi kebutuhan belajar warga usia belajar yang memiliki keterbatasan dalam pembiayaan sekolah. Dengan adanya para fasilitator belajar sangat membantu para anak PP untuk memiliki pengetahuan konsep, meningkatkan kemampuan motorik halus dan kasar, dan sikap yang dibutuhkan dalam rangka meningkatkan kualitas setiap anak PP, meningkatkan kesejahteraan hidup khususnya kemampuan calistung, dan membangun kehidupan sosial dalam berelasi yang dinamis bagi warga usia belajar di lingkungan mereka (Fakhruddin, 2011).

Untuk menunjang kegiatan mengajar anak PP para fasilitator belajar membuat alat peraga yang menarik, menerapkan prosedur di dalam belajar, dan memberikan latihan-latihan dalam belajar sesuai dengan kebutuhan belajar anak PP. Namun, keberhasilan yang sudah dicapai oleh para fasilitator belajar masih belum maksimal, mereka masih menemukan kesulitan di dalam mengajarkan mata pelajaran pendidikan dasar seperti: Bahasa Indonesia, Matematika, IPS, dan IPA. Dengan kesulitan yang mereka alami, membuat para fasilitator belajar hanya mengajarkan hal-hal yang dasar atau mengerjakan pekerjaan rumah (PR) anak partisipan (PP) dari sekolah.

Berdasarkan evaluasi program yang dilakukan antara UPH-PGSD dan pihak mitra Yayasan Emmanuel, ditemukan beberapa fakta mengenai kesulitan yang dihadapi fasilitator belajar, antara lain: 1) mengajarkan mata pelajaran Pendidikan dasar; 2) merancang pembelajaran (RPP) dan penilaian dengan maksimal; 3) memilih strategi pembelajaran yang tepat; 4) memimpin sebuah komunitas pembelajaran dengan siswa pebelajar; 5) merancang sebuah pameran pembelajaran. Berdasarkan hasil evaluasi tersebut, maka diadakan kegiatan kelanjutan dari pelatihan level dasar ke tingkat level Pemberdayaan fasilitator belajar level dua. Pemberdayaan adalah kegiatan yang dilakukan untuk membangun suatu komunitas masyarakat yang mumpuni di dalam kemampuan yang mereka miliki, dengan memberikan latihan, memotivasi, menumbuhkan kesadaran akan potensi yang dimiliki setiap anak PP dan berusaha untuk mengembangkan kemampuan tersebut menjadi suatu tindakan nyata dalam kehidupan sehari-hari (Zubaedi, 2007).

Menurut Mustafa Kamil (2007), fasilitator belajar dalam pendidikan nonformal haruslah memiliki kemampuan, kompetensi dan keterampilan secara professional dalam merencanakan, melaksanakan, dan mengevaluasi sebuah kegiatan pembelajaran. Sesuai dengan tujuan dari kegiatan ini adalah untuk memperlengkapi para fasilitator belajar memiliki keterampilan mengajar dan penguasaan konten mata pelajaran Pendidikan dasar. Susunan kegiatan pemberdayaan fasilitator belajar yang dilakukan pada tingkat level dua ini adalah untuk: 1) menganalisis materi Bahasa Indonesia, Matematika, IPA, dan IPS kelas 1-3; 2) merancang sebuah pembelajaran dan penilaian; 3) membedakan strategi pembelajaran; 4) mengevaluasi manajemen kepemimpinan; dan 5) merancang sebuah pameran pembelajaran.

Tahapan-tahapan dalam sebuah pemberdayaan diantaranya adalah: 1) tahap penyadaran dan pembentukan perilaku. Para fasilitator belajar menyadari bahwa pelatihan level dasar yang sudah mereka jalani hanya pengetahuan awal saja mengenai pengelolaan sebuah pembelajaran. Melalui pelatihan pemberdayaan ini, para fasilitator belajar juga memiliki kesadarn dan kepedulian terhadap warga usia belajar yang ada di lingkungan mereka. Hal ini juga membuat para fasilitator belajar tertarik untuk mengikuti kegiatan selanjutnya. Dikarenakan dengan bertambahnya jumlah anak PP yang memiliki keberagaman kebutuhan belajar di lapangan.; 2) tahap transformasi pengetahuan dan keahlian keterampilan, perlu adanya pembelajaran dan pelatihan mengenai berbagai pengetahuan, dan keahlian keterampilan untuk memaksimalkan kegiatan pemberdayaan yang dilakukan. Dengan beragam kebutuhan di lapangan, para fasilitator belajar membutuhkan pengetahuan dan keterampilan yang lebih mendalam mengenai Pendidikan dasar. Dalam kegiatan ini, para fasilitator belajar diperlengkapi dengan pengetahuan dan praktik mengenai Pendidikan dasar.; 3) tahap peningkatan kemampuan intelektual dan keahlian keterampilan. Kegiatan pemberdayaan fasilitator belajar, para peserta dilatih untuk dapat mengelola sebuah pembelajaran dengan mandiri. Para 
fasilitator belajar juga diperlengkapi dengan pengetahuan dan keterampilan membuat sebuah kegiatan belajar mengajar secara mandiri di lingkungan tempat mereka tinggal (Muslim, 2012).

Hasil dan manfaat yang diharapkan dari pelaksanaan kegiatan pemberdayaan fasilitator belajar, antara lain: 1) mampu menganalisis materi Bahasa Indonesia, Matematika, IPA, dan IPS kelas $1-3$; 2) mampu merancang sebuah pembelajaran dan penilaian; 3) mampu membedakan strategi pembelajaran; 4) mampu mengevaluasi manajemen kepemimpinan; 5) mampu merancang sebuah pameran pembelajaran. Para fasilitator belajar juga mampu berperan dalam memberikan arah untuk menumbuh kembangkan kemampuan dalam diri anak PP secara keseluruhan dan maksimal (Inayah, Nur., 2017). Dengan pengetahuan dan keterampilan yang dimiliki, para fasilitator belajar dapat mengaplikasikannya ketika mengajar di lingkungan mereka tinggal.

Ketercapaian dari kegiatan pemberdayaan fasilitator belajar dilihat dari kehadiran para peserta, tugas-tugas yang diberikan pada aplikasi pembelajaran online, keaktifan peserta saat pembelajaran, dan penilaian yang diberikan oleh pihak pengajar. Keberhasilan kegiatan pemberdayaan fasilitator belajar juga dilihat dari pertambahan jumlah anak PP mereka.

\section{METODE}

Tahapan yang dilakukan dalam menyaring peserta kegiatan pemberdayaan fasilitator belajar level dua, antara lain: 1) lulus dari pelatihan level satu; 2) lulus wawancara baik dari pihak Yayasan Emmanuel dan Pengajar PGSD UPH; 3) mendapatkan rekomendasi dari pihak sekolah; dan 4) mendapatkan persetujuan dari orang tua untuk komitmen mengikuti kegiatan selama satu tahun.

Metode yang digunakan pada kegiatan pemberdayaan fasilitator belajar siswa SMA pada level dua berupa: 1) Pengajar menjelaskan materi; 2) sesi tanya jawab antara pengajar dan peserta; 3 ) latihan baik secara mandiri ataupun kelompok; 4) mentoring dalam kelompok; dan 5) presentasi tugas. Kegiatan dilakukan setiap hari Sabtu dua minggu sekali dari pkl. 09.00-15.00 secara tatap muka. Peserta kegiatan adalah siswa SMA kelas 2 dan 3 berjumlah 9 orang, serta lokasi kegiatan dilakukan di Sentul.
Menurut Edlin (2915), Konsep mentoring sama dengan pemberian teladan, dimana mentor menjalankan atau menggambarkan sebuah perilaku atau keahlian yang diharapkan akan dipelajari dan ditiru orang yang mengamatinya dalam hal ini para fasilitator belajar. Mentor membantu para fasilitator belajar dalam hal; 1) memahami materi yang diajarkan oleh para pengajar; 2) mengerjakan tugas; 3) membangun kepercayaan diri, 4) berkomunikasi baik dengan teman, yang lebih tua, dan yang lebih muda; dan 5) memberikan masukan dan saran dari setiap materi yang dipelajari. Mentor yang efektif adalah mentor yang menjangkau para fasilitator belajar baik secara kognitif maupun afektif. Dimana mentor peduli dan memiliki ekspektasi tinggi kepada setiap para fasilitator belajar, serta hal ini terlihat dari keterlibatan mentor. Kegiatan mentoring dilakukan oleh mahasiswa PGSD FIP tingkat tiga. Para mentor selain mementoring, mereka juga membantu dalam observasi perkembangan peserta selama kegiatan berjalan selama satu semester.

\section{HASIL DAN PEMBAHASAN}

\section{Pelaksanaan}

Kegiatan pertama dan kedua dilakukan dengan tatap muka sesuai dengan jadwal yang sudah dibuat. Namun, dengan terjadinya Pandemi Covid-19, maka kegiatan ketiga hingga kedelapan dilakukan secara online dengan menggunakan aplikasi pembelajaran Google Classroom dan Google Meet. Kegiatan online pun dilakukan dengan dua cara, yaitu sinkronus dan asinkronus. Untuk kegiatan sinkronus, dilakukan setiap Sabtu pkl. 10.00-12.00 dengan Google Meet, sedangkan untuk kegiatan asinkronus peserta diberikan tugas mandiri yang dibuat lebih sederhana dengan menggunakan aplikasi pembelajaran online Google Classroom. Adapun jadwal kegiatan yang dilakukan sebagai berikut:

Tabel 1. Susunan Topik Kegiatan Pelatihan

\begin{tabular}{ll}
\hline Tanggal & \multicolumn{1}{c}{ Topik } \\
\hline & Guru sebagai pemimpin \\
& Ekspektasi guru \\
22/02/2020 & $\begin{array}{l}\text { Manajemen kelas } \\
\text { Perkembangan Anak } \\
\text { Tugas: merancang sebuah rumah belajar } \\
\text { secara kelompok } \\
\text { Melanjutkan tugas merancang sebuah rumah }\end{array}$ \\
& \multicolumn{2}{c}{ Pendidikan }
\end{tabular}




\begin{tabular}{ll} 
& \multicolumn{2}{l}{ belajar secara kelompok } \\
22/05/2020 & Workshop Online: Fun Games, dan \\
& Presentasi Slide \\
$28 / 05 / 2020$ & Workshop Online: Lebaran Online \\
$06 / 06 / 2020$ & Workshop Online: Bermain/Hidup Sehat \\
$13 / 06 / 2020$ & Workshop Online: Membaca dan \\
menceritakan Kesukaanku (Storry Telling) \\
$20 / 06 / 2020$ & Workshop Online: Berkomunikasi \\
$27 / 06 / 2020$ & $\begin{array}{l}\text { Workshop Online: Review Workshop } \\
\text { (Nusantara }\end{array}$ \\
\hline
\end{tabular}

Pelaksanaan acara setiap Sabtu pkl. 10.00-15.00 sebelum Pandemi Covid-19
10.00-12.00
Pengajar menjelaskan materi
$12.00-13.00$
Ishoma
$13.00-14.45$
$14.45-15.00$
Aktivitas yang sesuai dengan topik dibimbing oleh 5 orang mahasiswa
15.00
Kesimpulan

Pelaksanaan acara setiap Sabtu pkl. 10.00-12.00 saat Pandemi Covid-19

10.00-12.00 Pengajar menjelaskan materi via daring

12.00-15.00 Pembelajaran mandiri melalui aplikasi pembelajaran

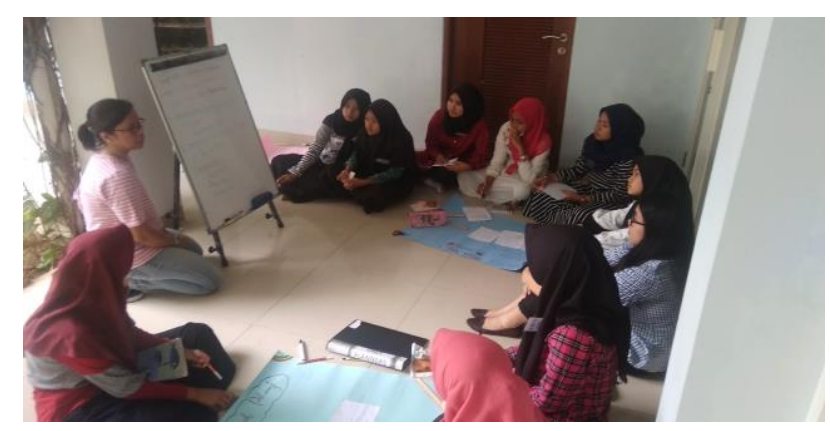

Gambar 1. Kegiatan Tatap Muka

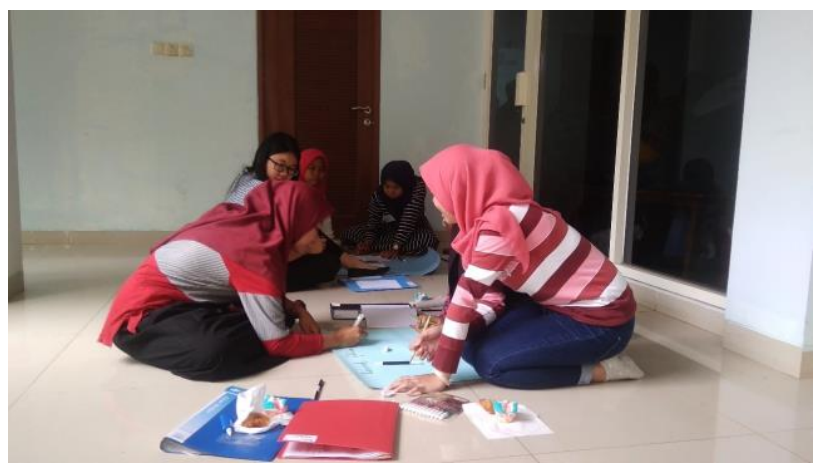

Gambar 2. Kegiatan latihan kelompok

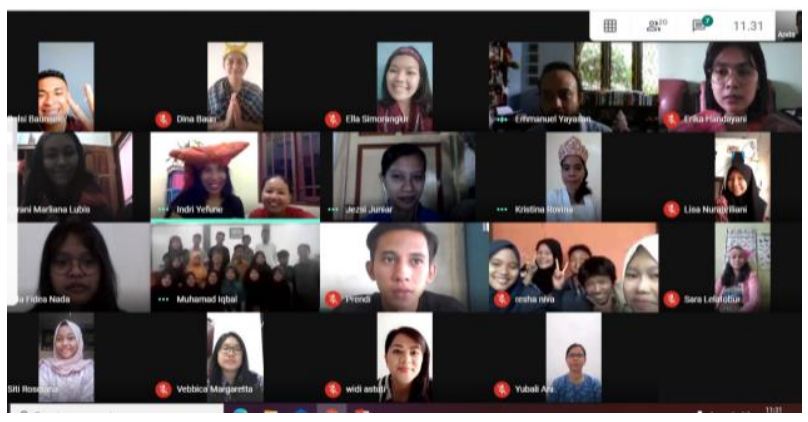

Gambar 3. Kegiatan Online Gabungan

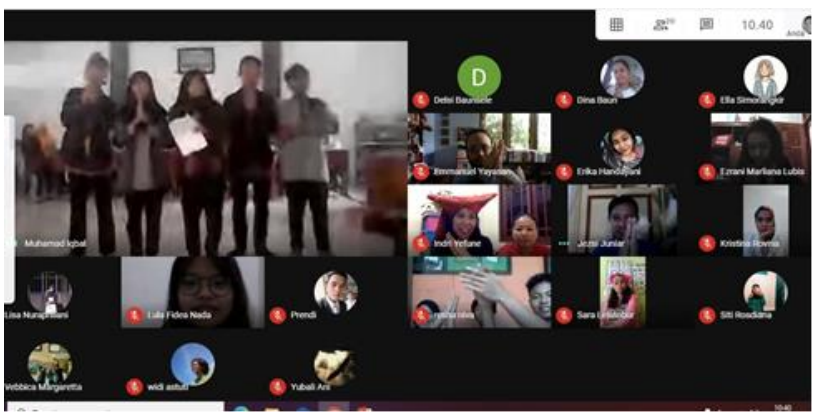

Gambar 4. Kegiatan Online Gabungan

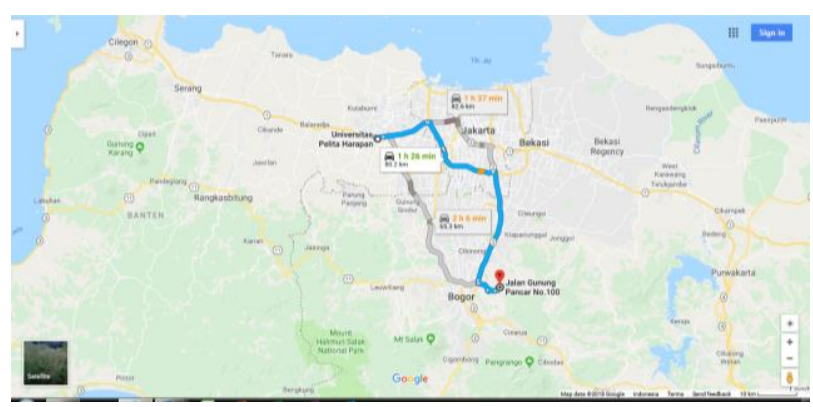

Gambar 5. Peta lokasi kegiatan

\section{Hasil}

Pada pelaksanaan kegiatan pertama dan kedua, para peserta dibagi dalam tiga kelompok untuk merancang sebuah rumah belajar. Dalam merancang sebuah rumah belajar dimulai dari tahap: 1) mengidentifikasi kebutuhan pelajar yang ada di lingkungan sekitar mereka dan menuliskan tujuan secara garis besar/umum dari rumah belajar tersebut; 2) melakukan analisis pembelajaran; 3) mengidentifikasi karakteristik dan perilaku para pelajar di lingkungan mereka; 4) menuliskan tujuan khusus dari rumah belajar atau hasil yang hendak 
dicapai; 5) menyusun strategi dan metode kegiatan yang akan dilakukan; dan 6) menyusun instrumen penilaian dari setiap kegiatan yang dilakukan saat di rumah belajar.

Hasil rancangan "rumah belajar" yang sudah dibuat belum maksimal untuk dipresentasikan, karena para peserta masih bekerja dalam kelompok untuk mendiskusikannya. Namun, dikarenakan kondisi Pandemi Covid-19 kegiatan secara tatap muka terhenti dan kegiatan dijadikan online. Rencana kegiatanpun berubah sesuai dengan kondisi peserta di lapangan menjadi online.

Kegiatan pemberdayaan fasilitator belajar level dua digabung dengan pelatihan fasilitator level satu untuk sinkronus, sedangkan untuk kegiatan asinkronus tetap disesuaikan dengan level kegiatan. Kegiatan dilakukan secara bersamaan antara peserta level satu dan level dua, dikarenakan ada beberapa kendala di lapangan, yaitu: 1) Peserta yang tidak memiliki HP dan keterbatasan kapasitas HP; 2) Sinyal yang kurang baik; 3) Kurangnya informasi tentang jadwal sinkronus untuk peserta yang rumahnya jauh dari sekolah dan peserta lainnya yang memiliki perangkat aplikasi online; dan 4) Peserta yang bekerja tidak bisa ikut sinkronus atau workshop secara langsung karena tidak dapat ijin libur dari tempat bekerja. Keterbatasan yang dimiliki peserta dalam memiliki perangkat, yaitu: 1) tiga orang memiliki HP; 2) lima orang menggunakan HP keluarga; 3) satu orang tidak memiliki HP; dan 4) lima orang HPnya tidak memiliki kapasitas yang memadai.

Kegiatan yang dilakukan selama pelatihan online dihadiri oleh peserta pelatihan level satu dan dua. Kondisi ini juga dikarenakan keterbatasan perangkat dan kendala sinyal di lapangan. Berikut adalah hasil kegiatan online baik sinkronus dan asinkronus.

Tabel. 2. Hasil kegiatan online level 2 baik sinkronus maupun asinkronus

\begin{tabular}{ll}
\hline Tanggal & Kegiatan dan kehadiran \\
\hline 22/02/2020 & Guru sebagai pemimpin \\
& Ekspektasi guru \\
& Manajemen kelas \\
& Perkembangan Anak \\
& Tugas: merancang sebuah rumah belajar secara \\
& kelompok \\
& Kehadiran tatap muka: $9(100 \%)$ \\
& Melanjutkan tugas merancang sebuah rumah \\
& belajar secara kelompok \\
& Tugas: merancang sebuah rumah belajar secara \\
& kelompok
\end{tabular}

Kehadiran tatap muka: 9 (100\%)

22/05/2020 Workshop Online: Fun Games, dan Presentasi

Slide.

Tugas: Identifikasi anak PP

Kehadiran sinkronus: 6 orang $(67 \%)$

Kehadiran asinkronus: 9 orang (100\%)

28/05/2020 Workshop Online: Lebaran Online

Tugas: Praktek Membaca

Kehadiran sinkronus: 5 (56\%)

Kehadiran asinkronus: 5 (56\%)

06/06/2020 Workshop Online: Bermain/Hidup Sehat

Tugas: Menulis lagu huruf, nama dan bunyi

huruf, huruf lepas, dan huruf sambung

Kehadiran sinkronus: 4 (44\%)

Kehadiran asinkronus: $6(67 \%)$

13/06/2020 Workshop Online: Membaca dan menceritakkan Kesukaanku (Storry Telling)

Tugas: Kuis tentang Tuna Grahita

Kehadiran sinkronus: 4 (44\%)

Kehadiran asinkronus: 5 (56\%)

20/06/2020 Workshop Online: Berkomunikasi

Tugas: Komunikasi sebagai pemimpin

Kehadiran sinkronus: $5(56 \%)$

Kehadiran asinkronus: 2 (22\%)

27/06/2020 Workshop Online: Review Workshop

(Nusantara

Tugas: -

Kehadiran sinkronus: 5 (56\%)

Total Sinkronus $62 \%$

Kehadiran Asinkronus $60 \%$

Berdasarkan tabel di atas, kehadiran para peserta level 2 secara sinkronus hanya $62 \%$ dan kehadiran 2 secara sinkronus hanya $60 \%$. Kehadiran sinkronus kurang maksimal dikarenakan peserta level 2 ada yang sudah lulus sekolah dan bekerja setiap hari, sehingga untuk tugas yang disubmit di Google Classroom secara asinkronus pun hanya $60 \%$. Kendala dalam submit tugas adalah karena keterbatasan kapasitas yang ada di HP.

\section{KESIMPULAN}

Kegiatan ini berjalan tidak sesuai dengan rencana, dikarenakan terjadi Pandemi yang mengharuskan kegiatan diubah menjadi pelatihan secara online. Pada kegiatan ini para peserta lebih dilatih untuk terbiasa menggunakan perangkat HP dan aplikasi yang ada didalamnya. Hal ini dikarenakan keterbatasan perangkat yang dimiliki oleh para peserta. Untuk mendukung kegiatan workshop ini sekolah dan Yayasan Emmanuel sangat membantu para peserta dalam mengikuti kegiatan, sehingga kegiatan dapat berlangsung

$$
\text { Pendidikan }
$$


dengan baik. Melalui pelatihan ini juga diberikan pelatihan bagaimana penggunaan perangkat dan aplikasi yang ada, sehingga kedepan diharapkan para peserta menjadi terbiasa dalam menggunakannya. Setelah para siswa terbiasa dalam penggunaan perangkat, maka untuk kegiatan selanjutnya diharapkan para peserta memiliki perangkat pendukung yang menunjang kegiatan belajar secara online. Kegiatan pada semester ini kami beri nama "Pra-kegiatan" dimana para peserta dipersiapkan dapat mengikuti kegiatan selanjutnya di semester depan.

\section{UCAPAN TERIMAKASIH}

Ucapan terima kasih kepada: 1) LPPM UPH dengan No. PM-032-FIP/I/2019; 2) Yayasan Emmanuel dan tim untuk dukungan moral dan moril yang diberikan selama kegiatan; 3) Dekan Fakultas Ilmu Pendidikan dan Ketua program studi PGSD; 4) Seluruh Pengajar, mentor, dan pihak yang mendukung PkM ini berjalan dengan baik.

\section{REFERENSI.}

Edlin, Richard. 2015. Hakikat Pendidikan Kristen. Jakarta: BPK Penabur.

Fakhruddin. 2016. Character Building Evaluation Model of Dialogical Learnig at Qaryah Thayibah Alternative School in Kalibening Salatiga Indonesia. The social science 11 (22): 5333-5337, 2016.

https://lib.unnes.ac.id/31122/1/1201413034.pdf

Fazrina, Dytta. 2016. Pemanfaatan hasil belajar pada pelatihan keterampilan mekanik otomotif. Universitas Pendidikan Indonesia. http://repository.upi.edu/20501/5/S_PLS_1001655_ Chapter2.pdf

Inayah, Nur. 2017. Peran tutor sebagai fasilitator dalam pendidikan keterampilan anak pesisir pada komunitas sahabat tenggang semarang. Unnes.

https://lib.unnes.ac.id/31122/1/1201413034.pdf

Kamil, Mustofa. 2007. Model Pendidikan dan Pelatihan. Bandung: Alfabeta. https://lib.unnes.ac.id/31122/1/1201413034.pdf

Majid, Abdul. 2013. Strategi Pembelajaran. Bandung: Remaja Rosdakarya.

Muslim, Azis. 2012. Dasar-Dasar Pengembangan Masyarakat. Yogyakarta: Samudra Biru. http://repo.iaintulungagung.ac.id/7928/5/BAB\%20II.pdf

Syamsi, Ibnu. 2010. Pendidikan Luar Sekolah sebagai Pemberdaya dalam Masyaraat. Jurnal Pendidikan Luar Sekolah: Volume 14, Nomor 1, Tahun 2010, ISSBN: 0854-896X. https://lib.unnes.ac.id/31122/1/1201413034.pdf

Sadiman, S Arieff, dkk. 2003. Media Pendidikan (pengertian, pengembangan, dan pemanfaatannya). Jakarta: PT Raja Grafindo Persada.

https://lib.unnes.ac.id/31122/1/1201413034.pdf

Yatimah, Durotul. 2015. Strategi fasilitasi perubahan sosial. http://sipeg.unj.ac.id/repository/upload/buku/III.A_. 1_.a_.2)_e)_(Buku_Strategi_Fasilitasi)_.pdf

Zubaedi, Wacana Pembangun Alternatif: Ragam Prespektif Pembangunan dan Pemberdayaan Masyarakat, (Jakarta: Ar Ruzz Media,2007), hlm 42. http://repo.iaintulungagung.ac.id/7928/5/BAB\%20II.pdf 